\title{
A BIM-Based Process from Building Design to Construction: A Case Study, the School of Melzo
}

\author{
Giuseppe Martino Di Giuda, Paolo Ettore Giana, Francesco Paleari, \\ Marco Schievano, Elena Seghezzi and Valentina Villa
}

\begin{abstract}
The digital transition in the construction industry is characterized by data and information management as central to a BIM process. The structuring of the design performance and data shared among the various stakeholders was designed to follow the entire building process: from the client requirements, up to the design, the construction phase and the final handover. The information workflow was drafted and validated on a new building school of Melzo case study.
\end{abstract}

Keywords School building design $\cdot$ Façade optimization $\cdot$ Building information management $\cdot$ Tender process $\cdot$ Construction management

\section{Introduction}

The new primary school of Melzo is designed to host 500 scholars, and is part of a wider programme for the school heritage set by the Municipality. The aim of this programme is the reorganization of existing building stock of the city. The final project was drawn up by the Municipality's UTC, as part of a research project in collaboration with the Politecnico di Milano for the development and implementation of the BIM processes for the management of the integrated contract, the tender with the most economically advantageous offer and support to works supervision for the controls in progress.

The project's aim was to create a morphological articulation capable of developing significant relations with the context, with specific attention to the internal-external relationship of the building. Particular attention was also paid to the study of an internal functional articulation that could be adapted to the needs of the contemporary school and tomorrow through a functional, flexible, unitary internal space.

G. M. Di Giuda $(\varangle)$ · P. E. Giana · F. Paleari · M. Schievano · E. Seghezzi

Architecture, Built Environment and Construction Engineering-ABC Department,

Politecnico di Milano, Milan, Italy

e-mail: giuseppe.digiuda@polimi.it

V. Villa

Department of Structural, Geotechnical and Building Engineering-DISEG,

Politecnico di Torino, Turin, Italy 
The building is composed of three functional units, characterized by different construction techniques and technologies: a central plug in reinforced concrete that connects all the rooms as well as the didactic direction containing the offices, the library and the auditorium; on the central corridor there are three elements with wooden structure, containing the classrooms and the laboratories; finally, a doubleheight body in reinforced concrete contains the canteen, the gym and the technical rooms for the systems.

Particularly strategic appeared the option of an optimal use of the open space, characterized by a good exposure and practicability: it is in fact possible to think of it as a sort of expansion outside the school. The treatment of the facades enhances this aspect: the large glass surfaces, which replace the conventional concept of window and are intended to enhance the continuity of perception with the natural environment outside, symbolically express the desire to open to the context (Tagliabue and Villa 2017).

The process was managed with a BIM-based approach; this paper presents its application in the different stages of the process.

\section{BIM Use During Tender Phases}

The research work aimed at defining criteria, sub-criteria, evaluation procedures, methods, and formulas to allocate points for a Most Economically Advantageous Tender (MEAT). The use of MEAT is limited in Italy, as it implies the use of precise and clear explanation of the points allocation, a proper use of this procurement method (meaning that the organizational conditions to use it should be made clear). Nonetheless, if properly used, MEAT processes result in advantages and transparency (Di Giuda and Villa 2015).

In this sense, the BIM methodology was used in this case both in the project design phase, and in the tender process drafting.

The proposed work tries to have as goal the definition of the criteria, the subcriteria, the evaluation procedures, the methods and the formulas to allocate points for a Most Economically Advantageous Tender. To the current state, in the tender notices is possible to often find requests of improvement of elements which are not included in the project, formulas of too generic or illegitimate bids which often to not report the explanation of the points allocation. Those factors necessarily entail a nontransparency in the work of the commission, which has to decide the procedures of points allocation during the appropriate session of evaluation. Therefore, incoherent data do not protect the contracting authority but, on the contrary, exposes it to a high litigation risk and to downwards negotiations during the execution of the work.

The tender process was managed through the use of the BIM project, as it included all graphic and performance information, organized in the database associated to the objects in the model. The model can be used to directly extract all the documents of the project and the tender information (graphic tables, and also documents, as Bill of Quantities, and performance specifications). The model was also used to obtain the 


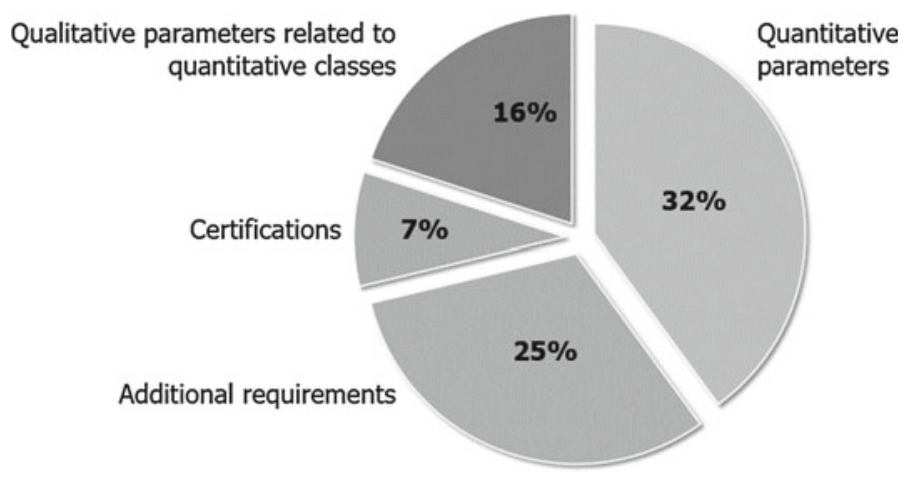

Fig. 1 Weight of proposed categories of parameters on the total score (image by authors)

bid sheets, useful to compose the guidelines for the compilation of the bid, attached to tender documentation (Di Giuda et al. 2015) (Fig. 1).

\subsection{Parameters for Bid Evaluation}

The integrated approach is outlined by innovation management system of the tender phase. In this sense, the methodology consisted in several steps. The first step is the parametric modeling of the building by the contracting authority. The model created is a virtual prototype of the project, consisting of virtual objects completely equivalent to the technical elements that constitute the building who will be assigned properties and attributes stored and managed by the database software. The model produced during the design phased was used to extract a coherent technical requirement document that contain the same information required by the client at the beginning of the design phase. This document constitutes the foundation of the "Allegato I" of the technical offer. Within the software criteria and sub-criteria of evaluation will be linked to objects on the form of parameters, which may already be present in the software or can be implemented manually. The contracting authority will draw in tabular form the latest information entered in the parameters, which are precisely the areas of activity of companies with respect to the project placed in the tender.

Analyzing the project was possible to identify the parts that could have been the subject of improvements. In particular, during the phase of use of the building, the focus was on the performance of the building envelope, on the performances of the plant machinery, on the hygiene and the managing of the resources. Another aspect on which the attention has been focusing on is the maintenance of the materials and the technological solution offered and the programmed maintenance of the architectural and plant design elements.

Each sub-parameter have been described in a thorough and punctual way the procedures of points' assignment, the formulas, the parameters of award, in order to 
the respect of the general principles related to transparency, non-discrimination and equal treatment. The points given to each part due to not alter the object of the award. In addition, the bids do not entail additional burdens for the contracting authority, but they have to guarantee improvements of the management, quality, or reliability of the contracting authority.

The parameters for bids evaluation were divided in four main categories:

- Quantitative parameters, that are valuable exclusively with mathematical formulas that have to be explained in the procedural guideline of the tender. Quantitative parameters include reduction of energy consumption, performances (thermal, acoustic, of resistance, etc.) of the materials or of technical solutions proposed, amount of waste and their management (reuse, recycling, disposal), cost of use and maintenance. Environmental parameters have been chosen in accordance to European Directive 2014/24/EU, stressing the importance of sustainable development and the potential contribution of contracting authorities to introduce environmental factors in tender notices. The calculation methods, the formulas and the pondering's parameters of the score have to be described in the tender and in the tender's procedural guideline, and the contacting authority has to provide all the information necessary to make the comparison competitive and equal.

- Qualitative parameters related to quantitative classes: every parameter in this category cannot be immediately identifiable through a numeric data, but can be related to "quality classes". These classes are defined in relation to technical requirements (for example, the maintenance of the expected solutions for the finishing on the pavement, siding, delivery conditions, services after the sell, technical assistance, etc.). The classes of quality can be defined in relation to the requirements of the contracting authority. Evaluation procedures, quality classes, and related points must be explained in the procedural guidelines of the tender.

- Qualitative requirements of subjective matters: this category regard all the cases where it is not possible to define objective qualitative classes. In these cases, it is mandatory to define precisely the object of the evaluation. It is also necessary to define the procedures for the evaluation. This category includes the evaluations related to the technical merit, the aesthetic and functional characteristics, the social characteristics, the organization of the personnel and everything not included in the points (a) (b) and (d).

- Additional requirements: this category includes certifications, and presentation of requirements additional to the ones which are strictly necessary for the participation in the tender. Examples of these aspects include: the rating of legality, the possession of environmental protection certifications (for example UNI ISO 14001) and certifications of management of health and security on the job (for example OHSAS 18001), etc., the possession of an ecological quality label of the European Union (Ecolabel EU) in relation to the goods and services listed in the agreement. It must be specified if the request of possession of one or more certificate, is made for the contracting company, for the entire group, or it is required from the suppliers (for example, for the materials with higher environmental impact) 
and the construction companies. In addition, it must enlist the relative scores and how the calculation procedures are made.

The parameters and sub-parameters are here presented (Table 1), with the assignment of the relative points of the tender for the new school in Melzo. The last column to the right illustrates the category of each sub-parameter.

A great support has been given with the use of "guidelines for the compilation of the technical offers" flanking the tender and the tender procedural guidelines. In it is described:

- The documents that constitutes the technical offer;

- The explanation of each parameter and sub-parameter;

- The formulas used for the definition of the weight;

- The list of the technical elements, which have been the object of the evaluation;

- The procedures of evaluation of each element;

- The definition table of the classes of quality;

- The formulas for the re-setting of the points.

\subsection{Scoring}

For each sub-criterion (Table 1), the procedures for awarding scores, formulas and award criteria have been described exhaustively and precisely, in order to comply with the general principles of transparency, non-discrimination and equal treatment. The scores attributed to the individual parts are such as not to alter the object of the award. Furthermore, bids must not entail any additional costs for the contracting authority, but must guarantee improved management, quality or reliability for the contracting authority.

In order to determine the ranking of the bids, it was decided to use the aggregative compensatory method. This method makes it possible to compare the bids with the project on which the tender was based and to evaluate the relative improvements. With regard to quantitative evaluation elements, or those related to quantitative elements, the score is evaluated through linear interpolation between the coefficient equal to one, attributed to the values of the elements offered most convenient for the contracting authority, and coefficient equal to zero, attributed to the values of the elements offered equal to those placed on the basis of the tender.

Automatic checks ensure that: if the bid is worsening or identical, in terms of quality or performance, to the project on which the tender is based, the score paid to the bid will be zero for the sub-criterion; this indicates that the solution offered is inadequate and, therefore, not assessable and not acceptable to the commission. 
Table 1 Criteria, sub-criteria, and scores of the evaluation

\begin{tabular}{|c|c|c|c|c|c|c|}
\hline Cod. & $\begin{array}{l}\text { Criteri di } \\
\text { valutazione }\end{array}$ & Peso & Cod. sub. & Subcriteri & Peso subcrit. & \\
\hline \multirow[t]{4}{*}{ A. 1} & \multirow{4}{*}{$\begin{array}{l}\text { Trasmittanza } \\
\text { involucro }\end{array}$} & \multirow[t]{4}{*}{10} & A.1.1 & Serramenti & 5,9 & (a) \\
\hline & & & A.1.2 & Chiusura verticale & 1,3 & (a) \\
\hline & & & A.1.3 & $\begin{array}{l}\text { Chiusura verticale } \\
\text { pref. } \\
\text { (palestra/mensa) }\end{array}$ & 1,7 & (a) \\
\hline & & & A.1.4 & $\begin{array}{l}\text { Copertura } \\
\text { palestra/mensa }\end{array}$ & 1,1 & (a) \\
\hline \multirow[t]{3}{*}{ A. 2} & \multirow[t]{3}{*}{$\begin{array}{l}\text { Requisiti materiali } \\
\text { offerti }\end{array}$} & \multirow[t]{3}{*}{10} & A. 2.1 & $\begin{array}{l}\text { Distanza Località } \\
\text { di prod. materiali } \\
\text { offerti }\end{array}$ & 3 & (b) \\
\hline & & & A. 2.2 & $\begin{array}{l}\text { Limitazione } \\
\text { ingombro delle } \\
\text { partizioni interne }\end{array}$ & 3 & (a) \\
\hline & & & A. 2.3 & $\begin{array}{l}\text { Grado di } \\
\text { manutenibilità dei } \\
\text { materiali offerti }\end{array}$ & 4 & (b) \\
\hline \multirow[t]{2}{*}{ A. 3} & \multirow[t]{2}{*}{$\begin{array}{l}\text { Requisiti } \\
\text { ambientali }\end{array}$} & \multirow[t]{2}{*}{5} & A. 3.1 & $\begin{array}{l}\text { Cert. UNI EN ISO } \\
14001 \text { impresa } \\
\text { affidataria }\end{array}$ & 2 & (d) \\
\hline & & & A. 3.2 & $\begin{array}{l}\text { Cert. UNI EN ISO } \\
14001 \text { prodotti } \\
\text { prevalenti }\end{array}$ & 3 & (d) \\
\hline \multirow[t]{2}{*}{ B.1 } & \multirow[t]{2}{*}{$\begin{array}{l}\text { Funzionamento } \\
\text { impianto }\end{array}$} & \multirow[t]{2}{*}{12} & B.1.1 & $\begin{array}{l}\text { Pompe di Calore } \\
\text { (PdC1, PdC2) }\end{array}$ & 6 & (a) \\
\hline & & & B.1.2 & $\begin{array}{l}\text { Unità di } \\
\text { Trattamento Aria }\end{array}$ & 6 & (a) \\
\hline B. 2 & $\begin{array}{l}\text { Componenti } \\
\text { impianto }\end{array}$ & 2 & B. 2.1 & $\begin{array}{l}\text { Distanza centro } \\
\text { manutenzione } \\
(\mathrm{PdC})\end{array}$ & 2 & (b) \\
\hline B. 3 & $\begin{array}{l}\text { Incremento energie } \\
\text { rinnovabili }\end{array}$ & 4 & B.3.1 & $\begin{array}{l}\text { Pannelli solari } \\
\text { fotovoltaici }(S \times \varepsilon)\end{array}$ & 4 & (a) \\
\hline \multirow[t]{2}{*}{ B.4 } & \multirow[t]{2}{*}{$\begin{array}{l}\text { Utilizzo } \\
\text { intelligente delle } \\
\text { risorse }\end{array}$} & \multirow[t]{2}{*}{7} & B.4.1 & $\begin{array}{l}\text { Sistemi di gestione } \\
\text { e riduzione del } \\
\text { consumo di energia } \\
\text { elettrica (solo } \\
\text { illuminazione) }\end{array}$ & 4 & (b) \\
\hline & & & B. 4.2 & $\begin{array}{l}\text { Sistemi di gestione } \\
\text { e riduzione del } \\
\text { consumo di acqua }\end{array}$ & 3 & (b) \\
\hline C. 1 & Sicurezza & 2 & C. 1.1 & $\begin{array}{l}\text { Certificazione } \\
\text { OHSAS } 18001 \\
\text { impresa }\end{array}$ & 2 & (d) \\
\hline
\end{tabular}


Table 1 (continued)

\begin{tabular}{l|l|l|l|l|l|l}
\hline Cod. & $\begin{array}{l}\text { Criteri di } \\
\text { valutazione }\end{array}$ & Peso & Cod. sub. & Subcriteri & Peso subcrit. & \\
\hline C.2 & $\begin{array}{l}\text { Soluzioni } \\
\text { costruttive, } \\
\text { Gestione cantiere }\end{array}$ & 13 & C.2.1 & Dettagli costruttivi & 6 & C.2.2 \\
\cline { 3 - 7 } & C.2.3 & $\begin{array}{l}\text { Layout di cantiere } \\
\text { (Fasi scavi e } \\
\text { strutture) }\end{array}$ & $\begin{array}{l}\text { Gestione } \\
\text { rifiuti/Sfridi (D.lgs. } \\
\text { 152/06) con part. } \\
\text { riferimento allo } \\
\text { smaltimento rifiuti } \\
\text { speciali }\end{array}$ & 3 & (c) \\
\hline D.1 & Man. parte Edile & 5 & D.1.1 & $\begin{array}{l}\text { Man. programmata } \\
\text { parte edile }\end{array}$ & 5 & (a) \\
\hline D.2 & $\begin{array}{l}\text { Man. parte } \\
\text { Impianti }\end{array}$ & 10 & D.2.1 & $\begin{array}{l}\text { Man. programmata } \\
\text { parte impianti }\end{array}$ & 10 & (c) \\
\hline
\end{tabular}

\section{Use of BIM During Tender}

An improvement of the procedure is represented by the integration of BIM methodology in the management of public procurement. In fact, if the proposed new method overcomes the discretion of the assessment by the Commission and makes objective evaluation criteria, a more advanced system management can leverage the BIM process to further expedite the procedure. In addition, the use of a single parametric model ensures completeness, consistency and homogeneity of information on the technical bids, reducing all the problems arising by the incongruity of the information.

During the publication of the tender, the contracting authority organized meetings to clarify potential questions, to explain the BIM methodology, to present criteria and sub criteria of the process. The use of guidelines for the compilation of technical offers was particularly helpful, as they described the required documents for the technical offer, the explanation of each parameter and sub-parameter, the formulas used for the definition of weights, the list of technical elements object of the evaluation, the procedures for the evaluation, the tables for quality classes definition, and the formulas for points resetting. Ten companies took part to the tender, but one did not deliver the whole documentation. Technical offers were filled in a thorough and detailed way, smartly combining parameters and sub-criteria to propose an improved offer. The values resulting from the offers demonstrate the truthfulness of the offers presented by the companies; the data were congruent, complete, and unequivocal. 


\section{Use of BIM During Construction Phases}

During construction phases, the Construction Manager was able to verify that all materials and products supplied on site corresponded exactly to the offer provided in the tender, in terms of performance and of brands proposed. This possibility stems from the request of the technical data sheets of all the materials and components during the tendering phase. The BIM model plays a role also in construction phase, as the quantitative and geometric control is carried out using the model, verifying not only the correct positioning of the elements installed on site, but also the dimensional correspondence and the fixing methods (Fig. 2). The checks carried out on the model during the design phase and the controls during the execution phase guarantee the quality of the work carried out in terms of interference between structural, plant engineering or architectural elements, guarantee the performance of the individual elements, already verified as a whole, and reduce possible variations or rework to a minimum (Eastman et al. 2016).

The advantages of the BIM methodology can be found in all the phases illustrated, starting from the selection phase of the contractor where the economic discount of $5 \%$ of the winning offer stands out. The scores, mainly calculated using mathematical formulas or quality classes, derived directly from the services provided in the technical sheets attached to the offers. A check was made of the correspondence and congruence between the elements making up the offer, with values close to $100 \%$. This eliminated any uncertainty in terms of design and technological choices and, consequently, the choice of brands and products to be implemented, greatly facilitating the process of verification and control in the execution phase.
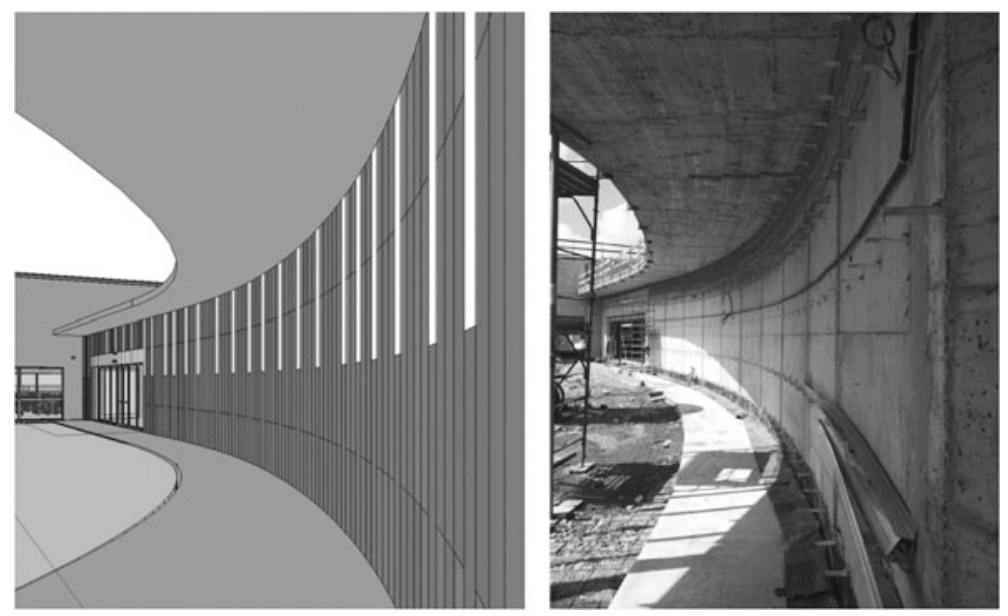

Fig. 2 Comparison between façade in the model and façade during building works (image by authors) 


\section{BIM for Advanced Project Activities}

A relevant element of the project is the curved façade cladded with coloured panels. The evaluation of the panels, in terms of quantity, dimensions, and pattern, was carried out through a script developed in Dynamo, and then linked to the BIM model (Fig. 3). This phase was carried out through a Design Optioneering approach, based on the setting of requirements conveying the needs of actors of the process, expressed in a quantitative form; each of them was then assigned a weight, to evaluate their mutual relevance in a multicriteria perspective.

The curved ventilated façade is composed of a metal structure, linked by fixing brackets to the concrete wall. The metal structure, composed of $t$-shaped steel profiles, acts as support for the cladding, made of high-pressure compact laminated panels. To create a pattern, the script included four inputs: the face of the geometry, width of panels, height of the coloured central panels, and RGB colours for the random pattern. The use of an algorithm allowed the creation of an adaptive family, embedded with the required parameters; the adaptive components were then placed on located points. The extraction of quantities from the BIM model allowed some considerations related to shape, costs, number of modules, and waste materials. A multi-criteria approach, based on the needs of the contractor, was used to evaluate the most suitable solution. This approach is particularly useful as it implies a tailored solution, based on stated needs and on quantitative evaluations, enhancing control over decision processes.

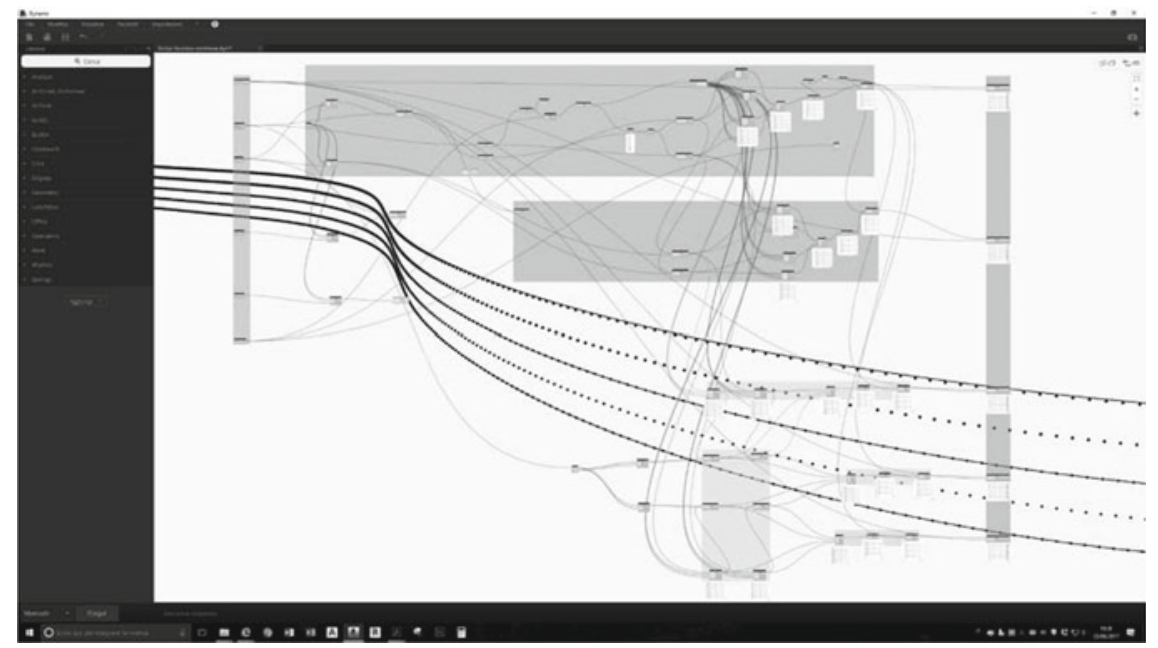

Fig. 3 Dynamo script of the ventilated façade (image by authors) 


\section{Limitations of the Proposed Method}

Since the use of BIM in the tender phase was not required, the entire process was conducted in parallel with the traditional management of documentation both in the tender phase and in the executive phase. The objective was not to overload the company and the designers, allowing them to concentrate only on the project and the works, using the model only as a verification and feedback in terms of performance for research activities on the subject. Since the use of an information exchange platform has not been contractually agreed upon, the procedure for acceptance and approval of materials by the Works Management is carried out in the traditional way by means of certified minutes and e-mails.

In parallel, the same documents are placed on an experimental platform connected to the modelled elements, in order to deliver to the client an as-built BIM-based model, containing all the information, documents, and photographs of construction.

\section{Conclusions and Further Outcomes}

Besides the presented limitations, Melzo school is an example of the use of BIM methodology to improve the quality of the process and of the final result. In this sense, the application of BIM methodologies to other parts (and phases) of the projects could result in an even higher level of quality.

The use of a BIM model for the building management could assure effective maintenance (both preventive and corrective), and successful use of the building. The integration of sensors, combined with the BIM model of the building, provides a complete and immediate state of the asset to technicians and facility managers. Sensors and actuators installed on the school will in fact provide data for the monitoring phase. Data collected could be used to analyse the real use of the building, resulting in an optimization of resources, both in terms of personnel and of energy and resources.

Considering the entire process, the BIM model could be joined by a DMS (Document Management System), in which the processes of control of the works can be structured: acceptance controls of materials, checks in progress, and archiving of documentation. The collaborative process could contribute to create a structured supply chain within the construction market, considering production and delivery times and guaranteeing on the reliability of products and teams in charge of the installation. This process has as goal an improvement in quality of the final product.

The proposed approach demonstrated to be a valuable method for the application of BIM-based methodologies in several phases of construction projects, thanks to its flexibility. 


\section{References}

Di Giuda GM, Villa V (2015) Verifica dei progetti e metodologia BIM, Ingegneri, nuove tecnologie, materiali, sistemi, processi, Maggioli Editore

Di Giuda GM, Villa V, Loreti L (2015) Il BIM per la gestione di una gara con il criterio dell'offerta economicamente più vantaggiosa-BIM to manage public procurement with award criterion Most Economically Advantageous Tender, Istea 2015: Sostenibilità ambientale e produzione Edilizia, Milano, 24-25 Sept

Eastman C, Teicholz P, Sack R, Liston K (2016) Il BIM Guida completa al Building Information Modeling per Committenti, Architetti, Ingegneri, Gestori immobiliari e imprese, Di Giuda GM, Villa V (eds). Hoepli

Tagliabue LC, Villa V (2017) Il BIM per le scuole. Analisi del patrimonio scolastico e strategie di intervento. A cura di Di Giuda, G M. Hoepli

Open Access This chapter is licensed under the terms of the Creative Commons Attribution 4.0 International License (http://creativecommons.org/licenses/by/4.0/), which permits use, sharing, adaptation, distribution and reproduction in any medium or format, as long as you give appropriate credit to the original author(s) and the source, provide a link to the Creative Commons license and indicate if changes were made.

The images or other third party material in this chapter are included in the chapter's Creative Commons license, unless indicated otherwise in a credit line to the material. If material is not included in the chapter's Creative Commons license and your intended use is not permitted by statutory regulation or exceeds the permitted use, you will need to obtain permission directly from the copyright holder. 